\title{
European Governance after Lisbon and Portability of Supplementary Pensions Rights
}

\section{Konstantina Kalogeropoulou}

\section{Introduction}

In the revised Lisbon strategy of 2005, the need to promote the European labour market was reinforced and 2006 was designated as the "European Year of Mobility for workers". "Within this context, the European Commission declared its intention to propose legislation on removing obstacles to labour mobility arising from occupational pension schemes (European Commission, 2005c). ${ }^{2}$

The need to remove obstacles for migrant workers was recognised from the inception of the EEC. Regulations 1408/71 and 574/72 were enacted on the legal basis of Article 42 EC, which provides for Community legislation to be adopted in the field of social security in order to provide the freedom of movement of workers. However, in relation to pension provisions, these Regulations cover only statutory pension schemes. ${ }^{3}$ The issue of enhancing portability of supplementary pension rights as a way of improving workers' mobility within the Member States has been attracting attention for more than fifteen years. ${ }^{4}$ Demographic changes and the Community goal of modernising social protection systems have further increased the focus on portability of supplementary pension rights. Nevertheless, at present, a clear legal framework safeguarding supplementary pension rights for EU workers and their family members does not exist. The main reasons for the lack of sufficient legislative measures protecting such rights can be attributed to the great heterogeneity between supplementary pension schemes and the fact that supplementary pension provisions form part of the national social security systems where the Community has restricted competence to intervene, as the Member States are primarily responsible for their organisation. The Open Method of Coordination (OMC), introduced at the Lisbon European Council in 2000, has provided the EU an alternative means, through soft law measures, to address such sensitive policy areas. From 2001, OMC was also applied to pensions. Although its effectiveness is not clear yet, it can provoke interest and engage the Member States towards the removal of hindrances in portability of supplementary pension rights. Alongside existing EU processes and the traditional Community method, portability of such rights may be promoted.

This article examines the main current EU governance structures relating to the portability of supplementary pension rights. After explaining what supplementary pension rights are, it describes the principal obstacles to their portability within the EU. It then considers the arguments for an improved portability of supplementary pension rights. Noting the Community's constrained competence in the field, it focuses on the use of soft law, in its 'old' form and how this has been and could further be used towards promoting portability of supplementary pension rights. Subsequently, 
a brief summary of existing 'classic Community method' measures is given, before turning to the use of the OMC in the pensions field, as a new soft law form of governance that could be used to advance the portability of supplementary pension rights within the EU. The article concludes with an analysis of the suitability of OMC as a tool for promoting portability.

\section{Obstacles to portability of supplementary pension rights}

Supplementary (occupational) pensions aim to supplement or substitute the basic pension income, provided by the State. ${ }^{5}$ They are characterised by their link to employment or professional occupation of the workers (occupational schemes) and generally form the second of a three-pillar classification ${ }^{6}$ of retirement provision that is adopted in the European Commission's documents. The first pillar includes the basic state pension schemes where the state guarantees the pension entitlements. Participation is generally obligatory and such schemes are generally managed by a public body and usually financed on a pay-as-you-go basis, which means that the contributions paid by active current workers towards their pension entitlements are used to pay the pension income of retired people. The third pillar also consists of supplementary pension schemes, which are however personal schemes that individuals can take out with insurance companies or other private financial institutions. Occupational pension schemes can be privately (usually) or publicly managed, may be set up by an employer or as a result of collective agreements or by a contract agreed either individually or collectively between the employer(s) and employee(s). They can further operate as unfunded or as funded, which is the most common form, and in which case the contributions paid in the occupational schemes are accumulated and invested and provide for the workers' future pension income. These can be defined benefits or defined contributions schemes. ${ }^{7}$ Participation may be compulsory or voluntary. ${ }^{8}$

Portability of supplementary pension rights means the possibility for EU workers to move either within the same or to a different Member State, for employment reasons, without losing or being disadvantaged in relation to their supplementary pension benefits. This article focuses on cross-border portability of supplementary pension rights for migrant workers (see Jacob, 2003; Andrietti 2001; Whiteford, 1995; Jolliffe, 1991). The main obstacles in relation to such portability of supplementary pension rights concern the acquisition, preservation and transferability of supplementary pension benefits when workers take employment in another Member State.

Acquisition of supplementary pension benefits may be subject to certain conditions, such as a waiting period (that requires an employee to be working for a particular employer for a certain time before he or she is allowed to subscribe to an occupational pension scheme); minimum age requirements; or the vesting period (which is the period a worker is required to have been subscribed to such a scheme for his pension rights to start being vested). Such conditions, that in some cases can be long and strict, 9 may for example prevent a worker from joining an occupational scheme in another Member State, or may prevent his rights in the scheme from vesting, before he moves to another Member State. Consequently, that worker will lose out on supplementary pension benefits in comparison to a worker who stays within the same occupational pension scheme in one Member State and for whom the contributions paid towards his supplementary pension income are not interrupted. ${ }^{10}$

Preservation concerns workers who move for work in another Member State, while their acquired pension benefits are left in the scheme related to the former employment. If these so-called dormant rights are not protected sufficiently, ${ }^{11}$ then by the time they are due to be 'collected', at retirement age, the worker may have been significantly disadvantaged, by comparison to what he would be entitled to, had he remained within the same pension scheme. 
Member State, mainly due to taxation practices (European Commission, 2001b) and through losses resulting from the calculations on the determination of the transfer value, or due to conditions set for transfers, or due to the inability to preserve them in the old scheme on the same conditions as above. The inability for workers to acquire, preserve or transfer their pension entitlements creates obstacles to free movement, as workers are thereby deterred from exercising this right. ${ }^{12}$

\section{The portability of supplementary pensions and the Lisbon Strategy}

The promotion of the free movement of workers has been one of the main goals of the European Community throughout the years of its development. This goal was established in Article 39 of the EC Treaty. Article 39 EC prohibits discrimination based on nationality between workers of the Member States as regards employment, remuneration and other conditions of work and employment, as well as rules that affect access of workers to the labour market. It also means that workers who exercise their right to free movement should not be faced with disadvantages in their social protection. Such disadvantages would deter them from exercising their right to free movement and would restrict labour mobility. The lack of a clear framework, safeguarding the supplementary pension rights of EU workers who take up employment within different Member States may result in workers who move between the Member States being penalised in relation to their supplementary pension entitlements, in comparison to the benefits they would have gained, had they stayed in the same Member State and supplementary pension scheme. Consequently, they might be discouraged from exercising their right to free movement.

The focus on workers' mobility was reinforced with the adoption of the Lisbon goal of becoming 'the most competitive and dynamic knowledge based economy in the world, capable of sustainable economic growth with more and better jobs and greater social cohesion' (European Council, 2000). This includes the goal of full employment that requires a skilled and adaptable labour force and the promotion of mobility within the 'new European Labour Markets' (European Commission, $2001 \mathrm{a})^{13}$ and consequently the removal of relevant obstacles, including those deriving from the inability to preserve supplementary pension rights.

The Lisbon strategy further focuses on the social character of the EU and the quality of social policy at European level. Social protection is now addressed on the same level as the EU's other goals. Reduced supplementary pension rights and consequently pension income would not only deter migrant workers from moving within the Member States, but would also diminish their level of social protection. Therefore the promotion of portability of supplementary pension rights would affect workers positively, on their decision to move to another Member State, when considering the financial implications and level of social protection. In its Social Policy Agenda (European Commission, 2000a) the European Commission identified again the need to remove obstacles to social security, resulting from supplementary pension provisions. A Pensions Forum 14 was set up to assist the European Commission in finding solutions to the problems and obstacles associated with cross-border mobility of workers in the area of supplementary pensions. ${ }^{15}$

The goal of modernising social protection that was reaffirmed in Lisbon ${ }^{16}$ further enhances the need for portability of supplementary pension rights. On the one hand, pension systems need to evolve to respond to the changes in the labour market. The traditional concept of life-long careers in the same employment position is changing. Modern labour markets require more flexibility and security to respond to the aspirations of mobile workers within the EU. Pension systems should not result in penalising job mobility, as may be the case with regards to the supplementary pension benefits of migrant workers who are suffering losses in their acquired rights. On the other hand, societal changes also call for the modernisation of social security systems and of pension provisions, in order to guarantee sustainable and adequate pensions. Demographic changes in recent years may have significant economic implications for the social protection systems of the Member States. Expenditure on the state pension schemes takes up a very high percentage of 
national spending on welfare. The decline of the number of births results in fewer active workers contributing to the national budget, while the rise of life expectancy means that pension benefits will need to be paid for a longer period of time to retired people. These factors may lead to a significant increase in public spending on pensions for the Member States. ${ }^{17}$

Various pension reforms focus on supplementary pensions, in order to respond to the pension challenges posed by the ageing population (see Marshall and Butterworth, 2000; European Commission, 2000b), as supplementary pensions are considered to shift some of this financial burden from the Member States that are in principle responsible for the state pensions, to funded supplementary pensions related to employment (occupational pensions). ${ }^{18}$ This move could help towards ensuring sustainable pensions. Safe and sustainable pensions and a higher pension income, supported by occupational pension benefits, would also respond to the societal need of providing adequate pensions that would enable the ageing population to maintain their standards of living after retirement and could further help towards promoting social inclusion. ${ }^{19}$ Therefore the need for portability of supplementary pension benefits has become more pressing. If this issue is not dealt with, it may either lead to fewer people who now join occupational pension schemes, moving within the EU for employment, as they would fear their pension income and social protection would be diminished or would not be secured if they moved. Alternatively, it may lead to employees being reluctant to join such schemes when taking employment in different Member States. This would in turn undermine the efforts to expand the use of such schemes that could help towards providing for adequate pensions. ${ }^{20}$ Accordingly, the European Council in Göteborg in 2001 endorsed three principles for securing the long-term sustainability of pension systems. Each of these can be related to supplementary pension provisions. These were: (1) safeguarding the capacity of systems to meet their social objectives: (2) maintaining their financial sustainability; and (3) meeting changing societal needs.

The re-launch of the Lisbon Strategy and the focus on growth and jobs (European Commission $2005 b)$, again brought attention to the need to ensure portability of supplementary pension rights. The integrated guidelines for growth and jobs (2005-2008, European Commission 2005d) further underline the need to attract and retain more people in employment and modernize social protection systems, and to improve adaptability of workers and the flexibility of labour markets, calling for the promotion of flexibility combined with employment security and the reduction of labour segmentation (Guideline 20). Therefore action for the possibility of workers to move within and between the Member States while not losing out on their supplementary pension income needs to be taken. In its work programme 2005, the European Commission announced the year 2006 as the "European Year of Mobility for Workers" as 'a means of promoting geographical mobility within and between Member States and a contribution to improving the efficiency of European labour markets, economic performance, the professional prospects of workers and the quality of living and working conditions' (European Commission, 2005a). The goal of promoting labour mobility by removing obstacles arising from occupational pension schemes should be reached by means of European legislation on portability of occupational pension to be adopted by 2007. To this end, the European Commission issued a proposal for a Directive on the improvement of portability of supplementary pension rights (European Commission, 2005e and 2005f; Pennings, 2005).

\section{Community competence}

Although portability of supplementary pension rights has been discussed for more than fifteen years and the European Commission has drawn attention on various occasions to the need to remove relevant obstacles in order to create a 'European pensions market', only very few measures of EU law that affect such portability exist. The lack of hard law on pensions at EU level is partly due to the complexity and diversity of different national systems and occupational schemes' provisions (Steinmeyer, 1992 and 2001). As noted above, throughout the Member States, there exist various types of occupational pension schemes. These differences indicate 
the heterogeneity in relation to the origin, scope and role supplementary occupational schemes hold within the Member States' social security systems. These depend on and reflect the different political, economic and cultural conditions that have affected their development. For example, in some Member States, supplementary pension provision covers a significant part of the population and provides for a high percentage of the overall pension income, while in others, reforms are currently taking place to introduce or enhance the role of supplementary pensions. Differences may also appear, for example, in relation to the contribution supplementary pensions offer to the income of retired people, or in relation to the total amount of assets held by private pension schemes, or even to the type of benefits provided (lump sums or annuities) and the ways risk for payments of pension income is shared. ${ }^{21}$ This makes the co-ordination of provisions that would reduce obstacles to free movement (i.e. on acquisition, preservation or transferability of supplementary pension rights) difficult to achieve.

The limited number of hard law measures at EU level on portability of supplementary pension rights is further due to the lack of direct legislative competence, at Community level, to intervene in the formation of national social security systems. The organisation of national social security systems and consequently the introduction of supplementary pension provision lie within the competence of the Member States. ${ }^{22}$ At European level, a concept of a European welfare state, which attributes individual social security benefits to EU citizens, does not exist. There is no provision in the EU Treaties explicitly regulating pensions. ${ }^{23}$ Furthermore, in many Member States, the pension systems are significantly affected by the role of social partners. This is particularly evident in occupational pension schemes based on collective bargaining, where the social partners are the main actors. Therefore, any Community action to intervene in the national rules for social security provision towards portability of such rights would need to respect the Member States' sovereignty in the social security field according to the principles of conferred powers and subsidiarity, as well as collective bargaining and the flexibility such negotiations require. ${ }^{24}$ Nonetheless, even if the provision of pensions are not a matter of EU 'responsibility', the connection of the issue of portability of supplementary pension rights to the internal market and social protection, has allowed for Community intervention (see Pochet, 2003; de Búrca, 2005)

The only provisions available in the Treaties in the field of social security that could be used to adopt legislative measures to promote portability of supplementary pensions benefits are Article 137 (2) EC, for the adoption of measures setting minimum standards, and Article 42 EC, which provides for the adoption of measures in the field of social security as are necessary to facilitate the freedom of movement for workers. ${ }^{25}$ Both legal bases require unanimity in the Council. Other Treaty provisions that may allow for the adoption of relevant measures are Articles 94 and $308 \mathrm{EC}$, again requiring unanimity in Council, based on the need to take action to fulfil the objectives of the Common Market. ${ }^{26}$ However, as discussed below, soft law mechanisms exist at EU level that could be used in parallel to, or instead of, legislative action, to promote portability of supplementary pension rights.

\section{Soft law-the 'old' approach}

Despite the restricted legislative competence of the Community in this field, another mode of European governance, that of soft governance, may allow intervention in the 'sensitive' areas of social security and social protection, where pension provisions are included. Community soft law in the form of non-binding measures taken by the EU institutions, imposing political burdens but bearing no legally enforceable obligations and sanctions for the Member States, provides for a flexible 'tool' towards policy making that can assist European integration and the realisation of Community objectives. Soft law has been widely employed in the areas of social policy. It can be used to draw attention to issues of common concern for the Member States, or as means of interpretation of hard law, or to enable the exchange of best practices and can possibly lead towards the adoption of legally binding measures (Snyder, 1993; Kenner, 1995; Hervey, 1998; Beveridge and Nott, 1998; Senden 2004). The nature of the different aspects that the need to 
improve portability of supplementary pensions and deriving rights touch upon, such as their link to modernisation of social protection and the need to provide for secure and sustainable pensions discussed above, further support the use of soft law in this area.

Various soff law initiatives and measures have been used in the last fifteen years towards enhancing portability of supplementary pension rights. In 1991, the European Commission, following the Action Programme to implement the Community Charter of the Fundamental Social Rights of Workers, issued a Communication to the Council (European Commission, 1991), where the contribution of supplementary pension schemes to the overall protection of workers and their implications for freedom of movement for workers were discussed. Furthermore two Council Recommendations, ${ }^{27}$ on the convergence of social protection objectives and policies and on sufficient resources and social assistance were issued. In the first Recommendation, the need to promote changes to the conditions governing the acquisition of retirement and especially supplementary pension rights with a view to eliminating obstacles to mobility, in order to adapt and develop social protection systems, was recognised. ${ }^{28}$ In 1995, there followed an attempt to generate a proposal for a Directive, but the issue was finally refereed to the High Level Panel on Free Movement of Persons chaired by Mrs Simone Veil (Tamburi, 1995). The Panel suggested the adoption of a Directive addressing the issues of preservation of acquired rights, cross-border payments and cross-border membership in the case of short-term employment in another Member State, as well as the creation of a Pensions Forum for debate and research into new initiatives on supplementary pensions. Subsequently, a Green Paper (European Commission, 1997b) and a communication (European Commission, 1999a) on supplementary pensions and the single market were issued by the European Commission. Following the report of the High Level Panel, two Directives (discussed below) were adopted to provide (limited) protection for supplementary pension rights for migrant workers. Furthermore, following various Lisbon strategy documents on the need to create flexible and adaptable markets and adequate social protection, the creation of the Pensions Forum, and the first and second stage consultation with the social partners, ${ }^{29}$ the recent proposal for a Directive on improving the portability of supplementary pension rights (European Commission, 2005e) was put forward by the European Commission. These legislative measures and initiatives indicate that soft law can add impetus in areas entailing common problems for the Member States and can result in the adoption of binding measures. ${ }^{30}$

\section{'Classic Community method' measures affecting portability of supplementary pension rights}

In spite of the interest the issue attracts, only a few legislative measures cover the subject. Directive $98 / 49 / \mathrm{EC}^{31}$ on safeguarding supplementary pension rights of employed and self-employed persons moving within the Community was the first such measure. This Directive does not deal with the conditions for acquisition, preservation, or transferability of supplementary pension entitlements, which are recognised as the main impediments to workers' mobility, and provides for only limited protection against the loss of supplementary pension rights. Its aim is to ensure that workers who move to another Member State are treated equally with workers who remain within the same Member State but for whom contributions are no longer being made into the scheme, as far as dormant rights are concerned. In addition, Member States must ensure that supplementary pension schemes make payments in other Member States of all benefits due to workers, net of any taxes and transaction charges that may be applicable. Finally, in relation to posted workers, contributions can continue to be made to the supplementary pension scheme in the workers' Member State of origin.

Directive $2003 / 41^{32}$ on the activities and supervision of institutions for occupational retirement provision aims to create a common legal framework at European level for the activities of such institutions as to allow them to fully benefit from the advantages of the Internal Market. It establishes the right for such institutions to manage pension schemes across borders and consequently allows multinational groups of companies to set up pan-European pension funds. These may 
facilitate labour mobility within these groups and could further provide for the safeguarding of supplementary pension rights for workers who move within the same or a subsidiary company that operates such a fund (see Hanlon 2004; Stevens, 2004; Birmingham, 2003).

However, the recently proposed Directive (European Commission 2005e) ${ }^{33}$, were it to be adopted, would provide for a significant step towards portability of supplementary pension rights. The proposed Directive aims to improve the conditions for workers to exercise their freedom of movement by removing obstacles to portability of supplementary pension rights (Pennings 2005). The draft Directive deals with the conditions for the acquisition and transferability of supplementary pension rights, and the rules on preservation of dormant pension rights. Nevertheless, the issue of taxation, which constitutes an important impediment to transferability of such rights, is exempted from the scope of the proposed Directive. Furthermore, some exemptions and transitional periods allowed $^{34}$ limit its scope. Overall, the proposed provisions seem to leave flexibility to the Member States to comply, taking into consideration the divergent national systems and the possible financial implications the relevant provisions could have for occupational schemes, ${ }^{35}$ as well as the fact that any action taken needs to be proportionate, and in accordance with the principle of subsidiarity, ${ }^{36}$ but does not eliminate all obstacles towards full portability of supplementary pension rights.

\section{The Lisbon strategy and the OMC as a new mode of governance}

In Lisbon, the open method of coordination was introduced as a new too ${ }^{37}$ to be used, alongside existing methods, towards the implementation of the new strategy, as the means of spreading best practice and achieving greater convergence towards the main EU goals (see de la Porte and Pochet, 2001; de la Porte, 2002; Scott and Trubek 2002; de Búrca 2003; Regent, 2003; Zeitlin, 2005). The OMC also constitutes a form of soft law, aiming at the co-ordination of national policies through political consensus and commitment to shared objectives and without the need for legislative actions or legal sanctions at Community level. The OMC may be differentiated from some other types of the 'old' approach to soft law (for example, the recommendations discussed above) by reference to its composition and functioning. The OMC constitutes not only a 'provision' but further a 'process' (Regent 2003). Even though it is a soft law policy tool, it can generate the adoption of hard law measures at national level. Even if it bears no formal sanctions and allows for flexibility, the 'review' system it establishes puts political pressure on the Member States and may also significantly restrain and guide their choices and policies. In this respect, it provides a new governance model (Regent, 2003; de la Porte and Pochet, 2003; Scott and Trubek, 2002). This is further enhanced by the incorporation in the EC Treaty of the Employment Title and Article $128 \mathrm{EC}$ as well as from Article 137(2)(a) EC as amended by the Treaty of Nice, that generally describes the $O M C$ process. In addition, the process that the $O M C$ entails emerged within a momentum created in the mid 90s given the unemployment crisis and the resort to consensus building to deal with common challenges in the lack of alternative means. ${ }^{38}$ Similarly to the use of soft law mentioned above, the OMC also provides a way for the Community to overcome the obstacles that national differences pose in the process of EU integration and to engage in social policy in politically sensitive areas such as pensions, where Member States have primary competence or discretion to control, while mobilising all relevant actors. In addition, the OMC, as a soft political instrument, enables the Community to act in order to address the implications of negative market integration on national social policies, and respond to new challenges posed at European level in this area, while respecting the autonomy and diversity of national rules and systems and being in conformity with the principle of subsidiarity. Such a challenge was the Community goal of adapting social protection systems and making pensions safe and pension systems sustainable.

In 2001, three broad principles for ensuring the long-term sustainability of pension systems were endorsed by the European Council in Göteborg. ${ }^{39}$ Recognising the need for an integrated approach of national strategies (European Commission 2001c) to face the common challenges 
in the area of pensions, and following a joint report by the Social Protection Committee and the Economic Policy Committee (2001) addressed to the European Council, in Laeken in 2001, the OMC was employed in the area of pensions with a view to creating a framework for policy cooperation to help the Member States towards securing adequate and sustainable pensions. Several of the objectives specified are directly affected by the role and development of supplementary schemes. Therefore the protection of supplementary pension rights of migrant workers is required for such schemes to be further promoted and the objectives set to be met.

Of the main objectives set, the one that could principally provide the basis for coordinated action towards portability of supplementary pension rights is the objective of ensuring that pension systems are compatible with the requirement of flexibility and security on the labour market and that labour mobility across borders and non-standard employment forms do not penalise people's pension entitlements or that self-employment is not discouraged by pension systems. ${ }^{40}$ The National Strategy Reports that are envisaged in the pensions OMCs, of 2002 and 2005, the Joint Report by the European Commission and the Council (Council of the EU, 2001) and the Synthesis Report (European Commission 2006a), verify this. In the first round, some Member States reported reforms in their systems in the context of the objective of adapting to more flexible employment and career patterns related to the promotion of labour mobility and portability of supplementary pensions. For example, Germany had halved the ten-year vesting period requirement to five years. Other Member States (Portugal, Spain, Italy) had indicated that they would take relevant measures to secure portability of supplementary pension rights for mobile workers (although this has not appeared in the second round of Reports). In the National Strategy Reports of 2005 however, four Member States (Denmark, Netherlands, United Kingdom and Germany) made specific reference to measures they had adopted in relation to such portability. ${ }^{41}$

Therefore, through the OMC and the monitoring and evaluation techniques it employs, a mutual understanding of occupational pension provision by Member States with different structures and perspectives on social security but that face similar problems with regards to the pension challenge and share common goals, may be achieved. (Amitsis, 2004). The flexibility of the OMC makes it suitable to be used in this area where such approximation of supplementary pension provisions through hard law is difficult to achieve. Also it provides for more flexibility for the national social security systems and for relevant provisions to adjust, respecting their diversity. In addition, it allows for the participation of all relevant actors at national and European level, such as the social partners that play a significant role in this field.

The OMC could lead to the gradual approximation of national provisions towards the elimination of obstacles to portability of supplementary pension rights. It could work along with other EU instruments ${ }^{42}$ and existing legislative measures (or the proposed Directive if adopted), as a means of interpretation. For example, ambiguity exists in relation to the definition of relevant terms such as the concepts of "fair adjustment" (Article 5) or "penalisation" of the outgoing worker (Article 6) used in the proposed Directive. OMC might also serve the implementation of provisions that provide the Member States with flexibility with regard to their application: for instance, the transitional period for the application of the provision concerning the vesting periods envisaged in Article 4 of the proposed Directive. The OMC could be used to indicate best practices in complying with these provisions, that would amount for instance to lower administrative costs for employers and better security for the pension benefits of the employees. This may be of particular assistance for some of the new Member States where occupational pensions are in the process of developing. Furthermore, the OMC could be applied in issues not dealt with by the proposed Directive, such as the coordination of taxation practices. ${ }^{43}$ Given that the proposed Directive only sets minimum requirements, the exchange of information and mutual learning the OMC allows for could lead to even more advantageous provisions at national level for portability of supplementary pension rights. Lastly, if the adoption of legislative measures at EU level fails, the OMC, could provide the means for an alternative way towards national reforms and the approximation of provisions that now impede portability of supplementary pension rights. ${ }^{44}$ 
In May 2003, the European Commission proposed to "streamline" the work on inclusion, pensions and health and long-term care, in an integrated OMC process (European Commission 2003). This would enable the creation of a stronger process that would integrate better with the revised Lisbon process and in particular with the EES and Broad Economic Policy Guidelines. ${ }^{45}$ In the new common objectives proposed (European Commission 2005g), three overarching objectives provide for a general framework for the work on OMC as a whole, while three groups of objectives are further envisaged for each specific policy area. It will be interesting to examine whether the next Reports of the Member States expected in 2006, refer to any other measures taken within the scope of the new objectives towards promoting portability of mobile workers.

\section{Is OMC an appropriate tool for promoting portability of supplementary pension rights?}

Although soft law has been used in relation to portability of supplementary pension rights and the OMC seems an appropriate tool to address the related problems, there is some scepticism about the use of soft law in the field of social policy, and especially in relation to this new type of policy making (de la Porte, 2002). An important argument concerns the legitimacy of the use of OMC (Zeitlin, 2005; Sypris, 2002). The tension focuses around the actual expansion of Community activities in areas of limited competence, considering also the notion of conferred powers. Another issue arises with regards to whether OMC will serve towards enhancing the social character of Europe, as an alternative to Community social legislation. In this view, OMC is considered a threat to the classic Community method, which provides for enforceable rights (Trubek D. and Trubek L, 2005; Scharpf, 2002). In the context of supplementary pensions, the adoption of legislative measures at EU level, setting minimum standards in relation to the conditions for acquisition of supplementary pension rights, would provide for a more clear framework of protection of such rights for migrant workers rather than the gradual compliance of national practices. With regard to portability of supplementary pension rights, further scepticism arises concerning the effectiveness of the OMC, given the vast array of different national rules and provisions on supplementary pension schemes noted above. The strong political interests that exist in this field, along with the fact that the OMC bears no formal sanctions, further support these arguments. Scepticism however exists also in relation to the effectiveness of the OMC in general (Zeitlin, 2005). In the pension OMC this is more evident (see Amitsis et al, 2003; European Commission, 2006b). In particular, instead of National Action Plans, only National Strategy Reports were required, in a three year circle, that describe mainly their national policies rather than action taken by the Member States, while the Joint Report adopted by the Spring Council in 2003 and the Synthesis Report in 2006, did not list best practices ${ }^{46}$ (see Eckardt 2005; de la Porte and Nanz 2004). Compared to the detailed annual monitoring of the EES, the pension OMC appears as a 'softer' process (de la Porte and Pochet, 2003; de la Porte and Nanz, 2004). The streamlining of the OMCs on pensions, social inclusion and healthcare and long-term care is intended however, to make the EU level coordination in the area of social protection more effective.

\section{Conclusion}

Portability of supplementary pension rights is a pressing issue that has to be addressed towards achieving the goals the Community has set itself. The interrelation of the goal of promoting free movement of workers with the societal needs and the focus on the European social model further attracts attention to this concern. The different rationales that underpin the necessity to improve such portability allow for different tools of policy making to be used. Hard law measures focus more on the internal market perspective while a softer mode of governance could justify Community action at EU level in the field of social protection. Despite the obstacles posed to portability of supplementary pension rights, the EU may now engage in this issue employing different measures. The OMC is being used in the area of pensions and could affect national provisions regulating the conditions for portability of supplementary pension rights. In parallel, soft law is used towards enhancing legislative interest in this subject. The European Commission has 
recently proposed the adoption of legislative measures (European Commission 2005e) towards safeguarding such rights. All these mechanisms, working together, could lead gradually to the facilitation of portability of supplementary pension rights.

\section{Notes}

* I would like to thank Professor Tamara Hervey and Professor Jeffrey Kenner for their helpful comments on a first draft of this article. All mistakes are my own. I gratefully acknowledge the support of the Greek State Scholarship Foundation (I.K.Y.).

1) Geographical mobility is relatively low between the EU countries. Between 2001 and 2002, just $0.2 \%$ of the EU population moved from one Member State to another. Comparing figures for 1999 indicate that while only $1.4 \%$ of the EU employed population had changed residence between regions, 5.9\% of the total population of the US had changed residence between countries within that period. (Employment in Europe 2001 - Recent Trends and Prospects, European European Commission 2001)

2) The European Commission had previously affirmed its intention to make proposals on portability of supplementary pensions. See Presidency Conclusions of the Stockholm European Council, 23-24 March 2001, par. 15 and European Commission (2002), "European Commission's Action Plan for skills and mobility".

3) These Regulations may also apply in relation to second pillar pension schemes that operate on a pay-as-you-go basis, discussed below.

4) The limited rates of mobility indicated above have raised questions about the actual need for enhancing portability of supplementary pension rights for migrant workers. However the argument may be reversed to claim that the lack of a sufficient legal framework with respect to certain aspects of free movement, such as portability of supplementary pension rights, is restricting mobility.

5) This section draws on Kalogeropoulou (2006).

6) This categorisation is not always followed. (For a different approach, see the Report of the Social Protection Committee on Privately Managed Pension Provision.) In addition, the boundaries between the three pillars are not always clear and different views may exist in relation to which pillar a pension scheme may belong. This distinction is adopted in the various European Commission Communications but is not adopted in the relevant existing legislative measures (Directive 98/49EC, see further below, and draft Proposal (European Commission 2005e)).

7) In defined benefits plans, the worker will be entitled to benefits defined in advance, calculated by a predetermined formula (for example taking into account the years of employment, or the years of service in combination to the salary of the employee). In defined contribution plans, the employee will take a pension income based on the result of the investment of the contributions made on his behalf.

8) According to Directive 98/49/EC (O.J. 1998, L 209/46) supplementary pension scheme means "any occupational pension scheme established in conformity with national legislation and practice such as a group insurance contract or pay-as-you-go scheme agreed by one or more branches or sectors, funded scheme or pension promise backed by book reserves, or any collective or other comparable arrangement intended to provide a supplementary pension for employed or self-employed persons".

9) For example in Luxembourg generally schemes apply a vesting period of five years, while current legislation actually foresees that waiting and vesting period should not exceed 10 years. In Germany vesting periods can be up to five years while the minimum age up to 30 (European Commission, 2005f).

10) The justification for these conditions lies in the fact that traditionally, occupational schemes aimed to reward loyal employees. Furthermore in some cases the subscription of an employee to an occupational fund for only a small period of time, could amount to a disproportionate administrative burden.

11) Possible ways to protect such rights would include, for example, adjusting them to inflation or at the same rate as pensions in payment or according to the general wage development or linking them to the rate of return of the assets of the institution for supplementary retirement provision.

12) One way to facilitate the movement of workers would be the possibility of cross-border membership to occupational pension schemes, as this would allow workers moving to one country, to remain affiliated in the previous occupational pension scheme without suffering losses resulting from changing schemes. Directives 98/49/EC and 2003/41/EC, discussed further below, facilitate cross-border membership, albeit for specific groups of workers. Obstacles to cross-border affiliation result for example from the tax treatment of cross-border payments of pension contributions or from the requirement of compulsory membership in an occupational pension scheme in the 'host' state. 
13) In this Communication, the need to eliminate barriers for workers posed by the lack of portability of supplementary pensions was again stated. The High-Level Task Force on skills and mobility that was set up to examine barriers to the European labour market underlined the need to attain a higher occupational and geographic mobility and a more integrated labour market and noted that there is no guarantee that supplementary pensions are transferable.

14) European Commission Decision 2001/548/EC.

15) The creation of the Pensions Forum was proposed by the European Commission in the Social Policy Agenda 2000-2005. The idea was first put forward by the High-Level Panel on Freedom of Movement, chaired by Mrs Veil, and was supported by the European Commission in its Communication 'Towards a single market for supplementary pensions' (European Commission 1999a). Following the Action Plan for Skills and Mobility (European Commission, 2002a), the European Commission launched consultations with the social partners. In the first stage (SEC (2002) 597, "First stage consultation of social partners on the portability of supplementary pension rights", published on 27.05.2002), the social partners were asked to give their opinions on possible Community action on the portability of pensions, while in the second phase (SEC (2003) 916, "Second stage consultation of social partners on measure to improve the portability of occupational pension rights", adopted on 12.09.2003), the possible content of such action was discussed. However, due to the divergent views on the instruments to be used to improve portability, they did not engage in negotiations with a view to reaching an agreement.

16) The European Commission had attracted interest on this issue before. See "The future of social protection: a framework for a European debate" (European Commission, 1995), "Modernising and improving social protection in the European Union" (European Commission, 1997a), "A Concerted Strategy for Modernizing Social Protection" (European Commission, 1999b)

17) The Stability and Growth Pact that followed the decision to adopt the EMU and the control of public deficit, along with the need of sound finances, poses further pressure on the Member States.

18) Or to individual schemes (third-pillar schemes).

19) On social exclusion and OMC see Armstrong (2003) and EXSPRO (2001).

20) At Lisbon in 2000, the European Council decided to mandate the High Level Working Party on Social Protection (this was replaced by the Social Protection Committee that was created in 2000) to prepare a study on the future evolution of social protection from a long-term point of view, with particular emphasis on the sustainability of pension systems. Consequently, the European Commission issued a communication on safe and sustainable pensions (European Commission 2000b), where the role occupational pensions may play towards achieving the overall objectives of pension systems was acknowledged. In the meantime, at Nice, the modernisation of social protection systems, was included within the objectives of the Community (as was the combating of social exclusion). However the possibility for the adoption of Directives was not extended to these areas. Article $137 \mathrm{EC}$ was amended to include Community action in the field of modernising social security systems and combating of social exclusion.

21) For specific country examples see the Report by the Social Protection Committee "Privately Managed Pension Provision".

22) Case 238/82, Duphar, [1984] ECR 523, para. 16; Cases C-159 and C-160/91, Poucet and Pistre, [1993] ECR I-637, para. 6; Case C-70/95, Sodemare, [1997] ECR I-3395, para. 27; Case C-120/95, Decker, [1998] ECR I-1831, para. 21; Case C-158/96, Kohll, [1998] ECR I-1931, para. 17; Case C-157/99, Geraets-Smits and Peerbooms, [2001] ECR I-05473, para. 44. However the Member States still need to "comply with Community law when exercising [their] powers" (Case C-120/95, Decker, para. 23; Case C-158/96, Kohll, para. 19; Case C-157/99, Geraets-Smits and Peerbooms, [2001] ECR I-05473, para. 44).

23) As national welfare provision is set according to national circumstances, Member States are even more reluctant to accept Community intervention in the organisation of their social security structures. This becomes even more complex because social security in general, and pension provision in particular, are linked to the national budget and taxation system and are often affected by the political context.

24) Any detailed coordinating or harmonisation measures on occupational pension provisions could undermine collective agreements. In addition, uniform requirements set by legislative measures could amount to excessive administrative costs for some schemes, that would burden the employer and would consequently result in reduced benefits for the employees. This situation could jeopardise the expansion of, or affiliation to such schemes.

25) The Court has ruled that "Article 42 [ex 51] provides for the co-ordination, not the harmonisation of the legislation of the Member states". Case 41/84 Pinna v. Caisse a'allocation familiales de la Savoie [1986] ECR 1, 24-5 (White, 1999).

26) Article $94 \mathrm{EC}$ (with Article $42 \mathrm{EC}$ ) has been used for the recently proposed Directive (European Commission 2005e), while Article 308 EC (with Article 42 EC) was used for Directive 98/49/EC. Article 95 EC may not be used for the adoption of measures promoting workers' mobility, according to paragraph (2).

27) Council Recommendations 92/441/EEC (OJ 1992 L245/46) and 92/442/EEC (OJ 1992 L245/49).

28) This was reaffirmed in the subsequent European Commission's Communication "Modernising and improving social protection in the European Union", (European Commission, 1997a).

29) Supra n 15.

30) In the area of social policy in general, examples like the focus in the 90 s on the issue of modernisation of social 
protection, that led to the reformed Article 137 in the Treaty of Nice, or the focus on employment, that resulted in Title VIII of the Treaty of Amsterdam, are further evidence that the use of soft law may significantly affect and help relevant issues develop.

31) OJ 1998, L209/46.

32) OJ 2003, L235/10. The Directive was adopted on the legal basis provided by Articles 47(2) EC on freedom of establishment, $55 \mathrm{EC}$ on freedom of services, and 95(1) EC on the approximation of laws.

33) It is worth noting that the Directive was based on the legal bases of Articles 42 and 94 EC. Article 137 EC that provides for the adoption of minimum harmonisation social policy directives in the field of social security was not used. This is reflected in the aim of the directive, which is primarily to facilitate labour mobility towards enhancing the internal market, rather than to protect pension rights of mobile workers, as social security rights.

34) For example, the Member States may be granted, where necessary, an extension of 60 months in relation to the reduction of the vesting period to the maximum of two years. The Member States may also exempt pay-as-you go schemes, support relief funds and companies that constitute book reserves, with a view to paying pensions to their workers from the application of the provision on transferability.

35) For example, excessive administrative costs deriving from the obligation to preserve dormant rights could dissuade employers from offering participation in such schemes or could amount to a reduction of the level of pension benefits.

36) However there have been criticisms that the draft proposal may restrict the role of social partners at national level, or that it could result in disproportionate administrative costs for the occupational pension schemes.

37) The OMC developed with the European Employment Strategy (EES-see Szyszczak, 2000; Ball, 2001; Kenner, 2003) in 1997, although this pattern had been developing since the mid 90s. It then expanded to several other fields (for example social exclusion, health and pensions) albeit the EES constitutes the more developed example.

38) The reform of Article $137 \mathrm{EC}$ to include the goals of social exclusion and modernisation also indicates the outcome of the consensus on modernising social protection (European Commission 1995, 1997a, 1999b) that led to this provision (see Szyszczak, 2002).

39) The application of the OMC in the area of pensions was previously decided in the Stockholm European Council, 23-24 March, 2001.

40) Others objectives include, for example, to provide access for all individuals to appropriate pension arrangements, public and/or private, towards maintaining, to a reasonable degree, their living standard after retirement; the objective of ensuring that private pension provision is adequate and financially sound, and should further allow the setting up of dedicated pension reserve funds; the objective ensuring that through appropriate regulatory frameworks and sound management, private and public funded pension schemes can provide pensions with the required efficiency, affordability, portability and security.

41) The UK government, for example, with the Pensions Act 2004 changed the maximum vesting period from two years to three months.

42) The pensions OMC was not meant to work on its own, but in conjunction with other existing processes, including the Broad Economic Policy Guidelines, the Stability and Growth Pact, aiming to ensure sound public finances, the European Employment Strategy, with the annual Employment Guidelines, and the Social Inclusion Process, aiming to combat poverty and social exclusion.

43) See Communication (European Commission 2001b). At the same time the European Commission is taking action against Member States for discriminatory taxation provisions. See http://ec.europa.eu/comm/taxation_customs/taxation/personal_tax/pensions/index_en.htm

44) The use of the OMC instead of hard law legislative measures provokes criticism. See further below, as well as the White Paper on European Governance (European Commission, 2001d) that states that the OMC should not replace Community action (pp 21-22).

45) A structure for reporting and evaluation covering the three fields as well as a timetable in accordance with the BEPGs and the Employment Guidelines, was proposed by the European Commission and supported by the Member States.

46) See Amitsis et al. (2003), that argue that in relation to the pension policies "there are no best practices as such", but only. 


\section{References}

Amitsis, G., Bergman, J., Hemerijck, A., Sakellaropoulos T., Stergiou, A., Stevens, Y., "Connecting welfare diversity within the European social model", background report, International Conference of the Hellenic Presidency of the European Union, 21-22 May 2003.

Amitsis,G., "The boundaries between Directive 2003/41 and the OMC process on occupational welfare", Public seminar on "Pensions at risk?", (Presentation Paper, European network for research on supplementary pensions, Leuven, 17.09.2004).

Andrietti V. (2001), "Portability of supplementary pension rights in the European Union" in 54 International Social Security Review 59.

Armstrong, K. (2003), "Tackling Social Exclusion through OMC: Reshaping the boundaries of EU Governance" in Borzel, T. and Cichowski, R., (eds.) State of the Union: Law. Politics and Society (Vol. 6) (Oxford: Oxford UP).

Ball, S. (2001), "The European Employment Strategy: The Will but not the Way?" 30 Industrial Law Journal 353.

Beveridge F., Nott, S. (1998), "A hard look at soft law" in P. Craig and C. Harlow (eds.) Lawmaking in the European Union, (Deventer: Kluwer Law International).

Birmingham, B. (2003), "All for one and one for all-The EU Directive allows cross-border pension funds", 9 Pensions 107.

Council of the EU (2001), "Quality and viability of pensions-Joint report on objectives and working methods in the area of pensions", 23.11.2001.

Council of the EU (2003), "Joint Report by the European Commission and the Council on Adequate and Sustainable Pensions", 10.03.2003.

De Búrca, G. (2003), "The constitutional challenge of new governance in the European Union" 28 European Law Review 814.

De Búrca, G. (2005), "Towards European Welfare" in G. De Búrca, (ed.) EU Law and the Welfare State (Oxford: Oxford OUP).

De la Porte C. (2002), "Is the Open Method of Coordination Appropriate for Organising Activities at European level in Sensitive Policy Areas?", 8 European Law Journal 38.

De la Porte, C., and Pochet, P. (2001), "Social benchmarking, policy making and new governance in the EU" 11 Journal of European Social Policy 291.

De la Porte, C., and Pochet, P. (2003), "Research on the OMC and European Integration: The OMC intertwined with the debates on governance, Democracy and Social Europe"unpublished report prepared for the Belgian Ministry of Social Affairs and Pensions. 
De la Porte, C., Nanz, P. (2004), "The OMC-a deliberative-democratic mode of governance? The cases of employment and pensions" 11 Journal of European Public Policy 267.

Eckardt M. (2005), "The open method of coordination on pensions: an economic analysis of its effects on pension reforms", 15 Journal of European Social Policy 247.

European Commission (1991) "Supplementary social security schemes: the role of occupational pension schemes in the social protection of workers and their implications for freedom of movement", SEC (91) 1332 final, 22.07.1991.

European Commission (1995), "The future of social protection: a framework for a European debate", COM (95) 466 final, 31.10.1995

European Commission (1997a), "Modernising and improving social protection in the European Union", COM (97) 102, 12.03.1997.

European Commission (1997b), "Supplementary Pensions in the Single Market-A Green Paper" COM (97) 283 final, 10.06.1997.

European Commission (1999a), "Towards a single market for supplementary pensions", Results of the consultations on the Green Paper on supplementary pensions in the single market, COM (1999) 134, 11.05.1999.

European Commission (1999b), "A Concerted Strategy for Modernizing Social Protection", $\operatorname{COM}(99) 347$ final, 14.07.1999.

European Commission (2000a), "Social Policy Agenda", COM (2000) 379, 28.06.2000.

European Commission (2000b), "The Future Evolution of Social Protection from a Long-Term Point of View: Safe and Sustainable Pensions", COM (2000) 622 final, 11.10.2000.

European Commission (2001a) "New European Labour Markets, Open to All, with Access for All", COM (2001) 116 final, 28.02.2001

European Commission (2001b), "The elimination of tax obstacles to the cross-border provision of occupational pensions", COM (2001) 214 final, 19.04.2001.

European Commission (2001c), "Supporting national strategies for safe and sustainable pensions through an integrated approach", COM (2001) 362 final, 03.07.2001.

European Commission (2001d), "European Governance, A White Paper", COM (2001) 428 final, 25.07.2001.

European Commission (2002a) "European Commission's Action Plan for skills and mobility", $\operatorname{COM}(2002) 72$ final, 13.02.2002. 
European Commission (2002b), "Free movement of workers - achieving the full benefits and potential" COM (2002) 694 final, 11.12.2002.

European Commission (2003), "Strengthening the Social Dimension of the Lisbon Strategy: Streamlining Open Coordination in the Field of Social Protection", COM (2003) 261 final, 27.05.2003.

European Commission (2005a), European Commission Work Programme for 2005, COM (2005) 15 final, 26.01.2005

European Commission (2005b) "Working together for growth and jobs A new start for the Lisbon Strategy", COM (2005) 24, 02.02.2005.

European Commission (2005c), Lisbon Action Plan Incorporating EU Lisbon Programme and Recommendations for Actions to Member States for Inclusion in their National Lisbon Programmes, SEC (2005) 192, Companion document to the Communication to the Spring European Council 2005 (COM (2005) 24) Working together for Growth and jobs, 03.02.2005.

European Commission (2005d), "Integrated guidelines for Growth and Jobs" (2005-2008), COM (2005) 141 final, 12.04.2005.

European Commission (2005e), "Proposal for a Directive of the European Parliament and of the Council on improving the portability of supplementary pension rights" COM (2005) 507 final, 20.10.2005.

European Commission (2005f), European Commission Staff Working Document, Annex to the 'Proposal for a Directive of the European Parliament and the Council on the improvement of portability of supplementary pension rights' SEC (2005) 1293, 20.10.2005.

European Commission (2005g), "Working together, working better: A new framework for the open coordination of social protection and inclusion policies in the European Union", COM (2005) 706 final, 22.12.2005.

European Commission (2006a), "Joint Report on Social Protection and Social Inclusion 2006 "- Synthesis report on adequate and sustainable pensions - $\{C O M(2006) 62$ final $\}, C O M$ (2006) 304, 27.02.2006.

European Commission (2006b), European Commission Staff working Document, "Evaluation of the open method of coordination for social protection and social inclusion. A synthesis of replies by Member States and other actors to an evaluation questionnaire on the Open Method of Coordination in the fields of social inclusion and adequate and sustainable pensions" SEC (2006) 345, 08.03.2006.

European Council (2000) Presidency Conclusions, Lisbon European Council, 23 and 23 March 2000. 
and Proposals for the Future Role of the EU", July 2001.

Hanlon. J. (2004), "Pensions Integration in the European Union" 29 European Law Review 74

Hervey, T. (1998), European Social Law and Policy, (Harlow: Longman).

Jacob R. (2003), European Commission, Directorate-General for Employment and Social Affairs, presentation on Portability of supplementary Pensions in the EU, CEPS Workshop, 28 February 2003.

Jolliffe, J. (1991), "The Portability of Occupational Pensions within Europe" in W. Schmahl (ed.)The future of basic and supplementary pension schemes in the European Community1992 and beyond (Baden-Baden: Nomos).

Kalogeropoulou, K. (2006), "Improving the Portability of Supplementary Pension Rights", 28 Journal of Social Welfare and Family Law 95.

Kenner, J. (1995), "EC Labour Law: The Soffly, Softly Approach" The International Journal of Comparative Labour Law and Industrial Relations 307.

Kenner, J. (2003), EU Employment Law, from Rome to Amsterdam and beyond, (Oxford: Hart Publishing).

Marshall J. and Butterworth S. (2000), "Pensions reform in the EU: the unexploded time bomb in the single market" 37 Common Market Law Review 739-762

Pennings, F. (2005), "Proposal for a directive on improving portability of supplementary pension rights" European Journal of Social Security 269.

Pochet P. (2003), "Pensions: the European Debate" in Pension Security in the 21 st Century edited by Gordon L. Clark and Noel Whiteside (Oxford: Oxford UP).

Regent, S. (2003), "The Open Method of Coordination: A New Supranational Form of Governance" 9 European Law Journal 190.

Scott, J., and Trubek, D. (2002), "Mind the Gap: Law and New Approaches t governance in the European Union" 8(1) European Law Journal 1.

Scharpf, F. (2002), "The European Social Model: Coping with the Challenges of Diversity" 40 Journal of Common Market Studies 645.

Senden, L. (2004), Soft Law in European Community Law (Oxford: Hart Publishing).

Snyder, F. (1993), "Soft law and Institutional Practice in the European Community", EUI Working Paper LAW No. 93/5 (Florence: EUI). 
Social Protection Committee (2005), "Privately Managed Pension Provision", Report by the Social Protection Committee, February 2005.

Steinmeyer H-D. (1990), "The Variety of occupational pension systems in the EC Member Stats as an obstacle for Mobility?" in 1992 and Beyond: An Explosion in Employee Benefits?, edited by Mary E. Brennan (CEBS, 25-26 October 1990, Amsterdam).

Steinmeyer H-D. (2001)., "Complementary Social Provisions and Mobility of Workers: 'Status Questions' in Comparative and European Law", Paper presented at the 6th International Colloquium-European Insurance Law, 'Complementary Social Provisions in the European Union-Pensions and Health Care', Brussels, December 19th and 20th, 2001.

Stevens, Y. (2004), "The meaning of 'national social and labour legislation' in directive 2003/41/EC on the activities and supervision of institutions for occupational retirement provision", Research report European Commissioned by the European Association of Paritarian Institutions (AEIP), Leuven 2004.

Sypris P. (2002), "Legitimising European Governance: Taking Subsidiarity Seriously within the Open Method of Coordination" EUI Working Paper LAW No. 2002/10.

Szyszczak, E. (2000), "The evolving European Employment Strategy" in Social Law and Policy in an Evolving European Union, edited by Jo Shaw (Oxford: Hart Publishing).

Szyszczak, E. (2002), "Social Policy in the Post-Nice Era in Accountability and Legitimacy in the European Union, edited by Arnull, A., and Wincott, D. (Oxford: Oxford UP).

Tamburi G. (1997), "The evolution of supplementary protection in the pension sector and the free circulation of individuals within the single market", in Social protection and the Single European Market, edited by Luigi Paganetto (CEIS 1997).

Trubek D., and Trubek, L. (2005), "Hard and Soft Law in the Construction of Social Europethe Role of the Open Method of Co-ordination" 11 European Law Journal 343.

Whiteford E. (1995), Adapting to change: Occupational Pension Schemes, Women and Migrant Workers (Deventer, Kluwer Law International).

Zeitlin, J. (2005), "Social Europe and Experimental Governance: Towards a New Constitutional Compromise?" in G. de Búrca (ed.) EU Law and the Welfare State (Oxford: Oxford UP). 